\title{
Analysis and Measurement of Current Distribution at Polymer Electrolyte Fuel Cell
}

\author{
Takuya Taniuchi Student Member (Toyohashi University of Technology) \\ Kenji Wakahara Student Member (Toyohashi University of Technology) \\ Mitsuyuki Nagahama Student Member (Toyohashi University of Technology) \\ Takuto Araki Member (Toyohashi University of Technology) \\ Kazuo Onda Member (Toyohashi University of Technology, onda@eee.tut.ac.jp)
}

Keywords: PEFC (polymer electrolyte fuel cell), membrane properties measurement, overpotential measurement, current distribution analysis

In order to grasp properly the power generation performances of PEFC (Polymer Electrolyte Fuel Cell), it is necessary to know the water management data, such as diffusion coefficient of water vapor through MEA (Membrane Electrode Assembly) and GDL (Gas Diffusion Layer), and electro-osmotic coefficient of MEA, and to know power loss data, such as activation and resistance overpotentials. In this study we have measured these data to analyze our experimental results of PEFC power generation tests by our two-dimensional simulation code. These data were adopted in our simulation code.

It is desirable to of develop the simulation code of PEFC power generation performance. By developing the simulation code of PEFC some experiments might be taken place by numerical simulations and could save the developing time and money. Therefore we have made a simulation code as a useful supporting tool of to develop PEFC. Our code considers simultaneously the mass, charge and energy conservation equations, and the equivalent electriccircuit for PEFC (Fig. 1) to get numerical distributions of hydrogen/oxygen concentrations, current density, cell potential, and gas/cell-component temperatures along gas flow. In this study current distributions of PEFC under a wide operating conditions have been calculated and compared with experimental distributions by our segmented electrode cell. The measured distributions under various operating conditions agreed well as shown in Fig. 2 with the calculated ones showing that our code is verified experimentally.

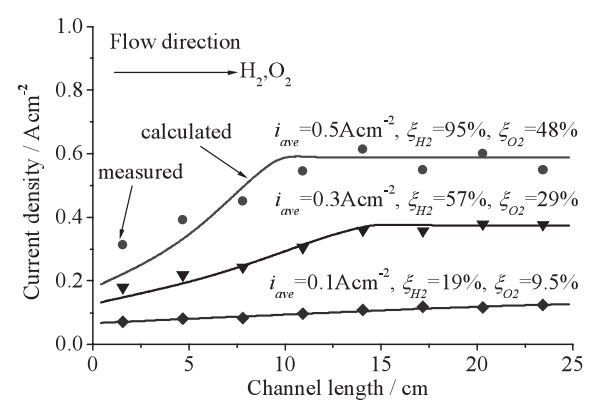

(a)
The current distributions shown in Fig. 2 were measured at an operating condition of low dew point temperature, medium $\mathrm{O}_{2}$ utilization ratio and co-flow type. In this condition the membrane resistance is high at cell entrance due to the dry anode and cathode gases, and at the middle of the cell the membrane is humidified by the generated water, keeping the same resistance along flow direction until the cell outlet. The concentration overpotential through GDL was also estimated by the parallel fine pores model, however the estimated concentration overpotential was very small to be neglected in the power generating performance of PEFC.

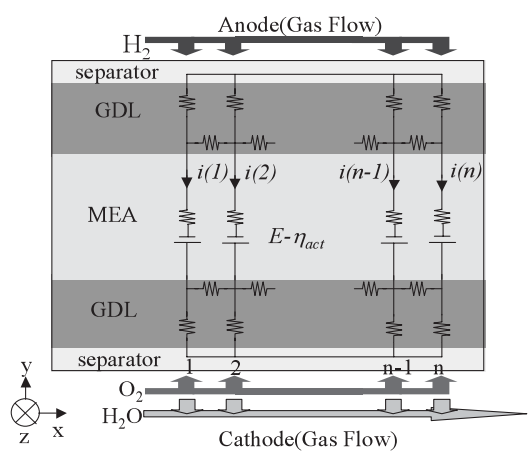

Fig. 1. Equivalent circuit of PEFC

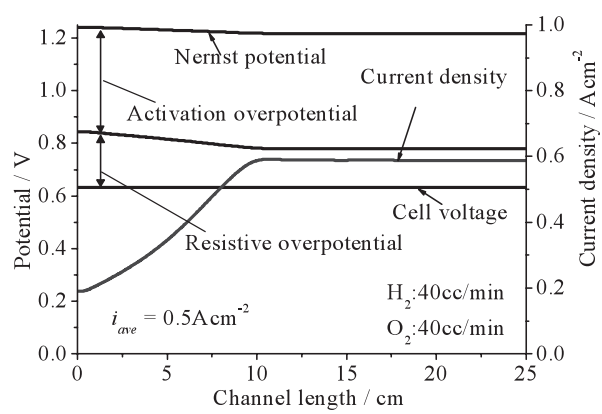

(b)

Fig. 2. Comparison between measured and calculated current distributions at low dew point temperature and medium $\mathrm{O}_{2}$ utilization ratio (co-flow) 


\title{
固体高分子燃料電池の電流分布解析と測定
}

\author{
学生員 谷内 拓哉* 学生員 若原 健二* \\ 学生員 長濱 光幸* 正 員 荒木 拓人* \\ 正 員 恩田 和夫*
}

\section{Analysis and Measurement of Current Distribution at Polymer Electrolyte Fuel Cell}

Takuya Taniuchi*, Student Member, Kenji Wakahara*, Student Member, Mitsuyuki Nagahama*, Student Member,

Takuto Araki*, Member, Kazuo Onda*, Member

In order to grasp properly the power generation performances of PEFC (Polymer Electrolyte Fuel Cell), it is necessary to know the water management data, such as diffusion coefficient of water vapor through MEA (Membrane Electrode Assembly) and GDL (Gas Diffusion Layer), and electro-osmotic coefficient of MEA, and power loss data, such as activation and resistance overpotentials. In this study we have measured these data to analyze our experimental results of PEFC power generation tests by our two-dimensional simulation code. Our code solves simultaneously the mass, charge and energy conservation equations, and the equivalent electric-circuit for PEFC to get numerical distributions of hydrogen/oxygen concentrations, cell potential, current density, and gas/cell-component temperatures. The current density distributions calculated by our simulation code were compared with the measured distribution by our segmented electrodes cell. The measured distributions under various operating conditions agreed well with the calculated ones showing that our code is reliable. The concentration overpotential through GDL was also estimated by the parallel fine pores model, but the estimated concentration overpotential was very small and could be neglected in the power generating performance of PEFC.

キーワード : 固体高分子燃料電池, 膜物性測定, 過電圧測定, 電流分布解析

Keywords: PEFC (polymer electrolyte fuel cell), membrane properties measurement, overpotential measurement, current distribution analysis

\section{1. まえがき}

性能に優れ価格も手頃な計算機が普及し, シミュレーショ ン技術も発達している現在, 多くの分野で計算解析ソフト は製品開発の強力な支援ツールとなっている。固体高分子 燃料電池 (PEFC) の開発が着実に進展している現在, その 特性解析ソフトを開発し, PEFC の力強い支援ツールに成 長させれば，PEFCの開発も更に加速されよう。解析プロ グラムにより発電性能が予測され，実験結果と照合しつつ 解析精度が向上すれば，多くの時間と費用を要す実験を数 值実験で代替でき，PEFCの開発速度を更に早めることが できよう。

PEFC の性能はセル内の水の挙動や過電圧などにより影 響されるので, PEFC の膜物性や過電圧を正確に把握する

\footnotetext{
* 豊橋技術化学大学 電気 · 電子工学系

干 441-8580 豊橋市天伯町雲雀ケ丘 1-1

Electrical and Electronic Eng., Toyohashi University of Technology

1-1, Hibarigaoka, Tenpaku-cho, Toyohashi 441-8580
}

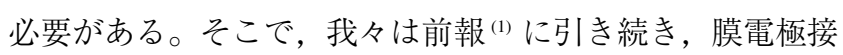
合体 (MEA) の水蒸気に対する拡散係数や電気浸透係数, ガス拡散層 (GDL) の水蒸気に対する拡散係数 ${ }^{(2)}$, また, 発 電特性を左右する MEA の膜抵抗や活性化過電圧を様々な 運転条件において測定し, 再整理した。次に, これら膜物 性などの測定結果を整理した式を用い, Nguyen ら ${ }^{(3)}$ の解 析法を MEA と GDL に分けてガス流路も含めて質量や熱 の収支が取れる解析法に発展させ, PEFCの発電特性を解 析した。更に解析結果の信頼性を実験的に確認するため, 分割電極セルでガス流路に沿う電流分布を測定し, 解析電 流分布と比較した。

このように, 本研究は PEFC の解析法を検討するのみな らず，実測したセルの重要な膜物性や過電圧などを解析に 取り組み, 解析した電流分布を実測分布と比較し, 解析の 信頼性を広い運転条件で確認したので報告する。

\section{PEFC の発電特性解析プログラム}

〈2・1〉 解析モデル 燃料電池セル内では発熱による 


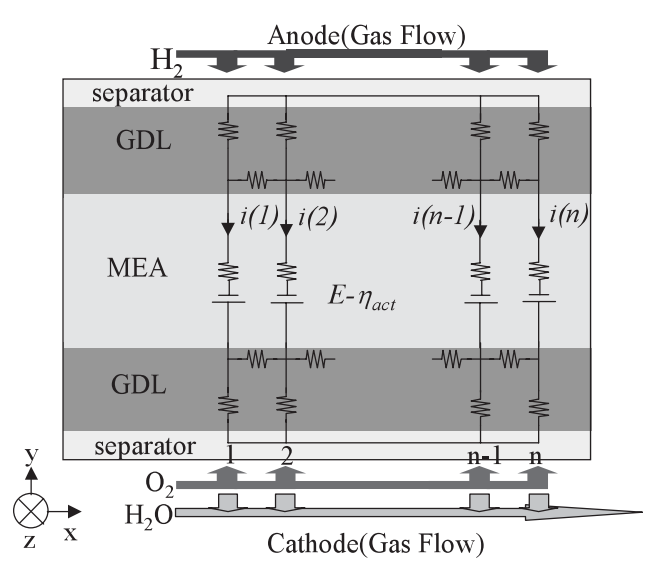

図 1 PEFC の等価回路

Fig. 1. Equivalent circuit of PEFC.

温度分布や，水素や酸素の消費や水の生成などによりネル ンスト起電力や活性化過電圧，膜抵抗がガス流れ方向に変 化し，電流や電圧の分布が決定される。そこで以下のよう に温度や電圧, 電流の分布が求められる解析コードを前報(1) に準じて構築した。以下に解析法の概要を述べる。解析は 図 1 のように供給ガスの流れ方向 $\mathrm{x}$ と膜の厚さ方向 $\mathrm{y}$ の擬 似二次元を考元, 物質・電荷収支式, 熱収支式, 等価回路を それぞれの計算領域で分割し，CV (Control Volume) 法を 用いて差分化し (1)，連立させて解き収束解を得る。y 方向 の分割は, Nguyen ら ${ }^{(3)} の 3$ 分割より多くし, 水素極流路 中の流体，水素極の GDL，MEA，酸素極の GDL，酸素極 流路中の流体と合計 5 分割し， $\mathrm{x}$ 方向にも分割したそれぞ れの領域は一つの代表值で記述し, 図 1 のように GDL の $\mathrm{x}$ と $\mathrm{y}$ 方向の抵抗を考慮し, Nguyen ら $^{(3)}$ より実際のセル に近い解析コードに改善した。なお，セパレー夕は等電位 と仮定した。 $\mathrm{xy}$ 平面に垂直な $\mathrm{z}$ 方向には諸量は一様に分配 すると仮定し，セルの 1 流路のみを解析し, 流路中の流体 は plug-flowとし，セパレー夕には恒温水を流したため，セ パレータ温度は一定とし, 生成水によるカソードのフラッ ディングは無視した。

$\langle\mathbf{2} \cdot \mathbf{2}\rangle$ 物質収支 流路および GDLでは，流体は気液 二相状態で, 消費される水素, 酸素や生成される水は流路 中では $\mathrm{x}$ 方向に, GDL 中では $\mathrm{y}$ 方向に流れ, 生成水は水の 飽和蒸気圧を超えた分は凝縮するとし, 凝縮係数 $k_{c}$ を 1 と した。流体は分割した各 CV 内で速度, 各化学種濃度, 温 度が一様な plug-flow とする。各化学種の物質・電荷収支 に関する基礎式は以下の通りである。

(水素極)

$$
\begin{gathered}
\frac{d M_{\mathrm{H}_{2}}}{d x}=-w_{\text {channel }} \cdot N_{\mathrm{H}_{2}}=-\frac{w_{\text {channel }} \cdot i(n)}{2 F} \cdots \cdots \cdots \cdots(1) \\
\frac{d M_{\mathrm{H}_{2} \mathrm{O}, a}^{l}}{d x}=\left(\frac{k_{c} \cdot w_{\text {channel }} \cdot t_{\text {channel }}}{R\left(T_{a}+273.15\right)}\right)\left(\frac{M_{\mathrm{H}_{2} \mathrm{O}, a}^{v}}{M_{\mathrm{H}_{2} \mathrm{O}, a}+M_{\mathrm{H}_{2}}} P-P_{\mathrm{H}_{2} \mathrm{O}, a}^{\text {sat }}\right) \\
\cdots \cdots \cdots \cdots \cdots(2) \\
\frac{d M_{\mathrm{H}_{2} \mathrm{O}, \mathrm{a}}}{d x}=-\frac{d M_{\mathrm{H}_{2} \mathrm{O}, a}^{l}}{d x}-\frac{\alpha \cdot w_{\text {channel }}}{F} i(n) \cdots \cdots \cdots \cdots(3)
\end{gathered}
$$

(酸素極)

$$
\begin{aligned}
& \frac{d M_{\mathrm{O}_{2}}}{d x}=-w_{\text {channel }} \cdot N_{\mathrm{O}_{2}} \\
& =-\frac{w_{\text {channel }} \cdot i(n)}{4 F} \\
& \frac{d M_{\mathrm{H}_{2} \mathrm{O}, c}^{v}}{d x}=-\frac{d M_{\mathrm{H}_{2} \mathrm{O}, c}^{l}}{d x}+\frac{w_{\text {channel }} \cdot(1+2 \alpha)}{2 F} i(n) \\
& \frac{d M_{\mathrm{H}_{2} \mathrm{O}, c}^{l}}{d x}=\left(\frac{k_{c} \cdot w_{\text {channel }} \cdot t_{\text {channel }}}{R\left(T_{c}+273.15\right)}\right)\left(\frac{M_{\mathrm{H}_{2} \mathrm{O}, c}^{v}}{M_{\mathrm{H}_{2} \mathrm{O}, c}^{v}+M_{\mathrm{O}_{2}}+M_{\mathrm{N}_{2}}} P-P_{\mathrm{H}_{2} \mathrm{O}, c}^{\text {sat }}\right) \\
& \alpha=n_{d}-\frac{F}{i(n)} D_{\mathrm{H}_{2} \mathrm{O}} \frac{d C_{\mathrm{H}_{2} \mathrm{O}}}{d y}
\end{aligned}
$$

$\langle\mathbf{2} \cdot \mathbf{3}\rangle$ 理論起電力と過電圧 理論起電力は以下の Nernst 式で定義される。

$$
E=E^{o}-\frac{R T_{M E A}}{2 F} \ln \frac{P_{\mathrm{H}_{2} \mathrm{O}, c}}{P_{\mathrm{H}_{2}} P_{\mathrm{O}_{2}}^{0.5}}
$$

ただし， $E^{o}$ は標準 Gibbs 自由エネルギー変化 $\Delta G^{o}$ で表せ るので, $\Delta G^{o}$ の温度変化を考慮し次式で表される。

$$
E^{o}=1.229-8.5 \times 10^{-4}\left(T_{M E A}-298.15\right)
$$

また, セル電圧 $V_{\text {cell }}$ は起電力 $E$ から活性化過電圧 $\eta_{\text {act }}$, 抵 抗過電圧 $\eta_{\text {ohm }}$ を引き, 次式で表される。

$$
V_{\text {cell }}=E-\eta_{\text {act }}-\eta_{\text {ohm }}
$$

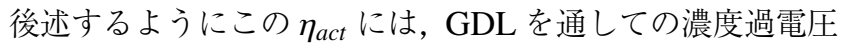
も含まれる。電流が分布する実際の PEFCでは GDL の $\mathrm{x}$ 方向の短絡抵抗を考慮して, 図 1 の等価回路を基礎収支式 と連立させる。

$\langle\mathbf{2} \cdot \mathbf{4}\rangle$ エネルギー収支 水素極流路, 水素極 GDL, MEA, 酸素極 GDL, 酸素極流路のそれぞれについて, $\mathrm{x}$, $\mathrm{y}$ 方向の熱伝導や熱伝達, エンタルピ移動, 過電圧やエン トロピ発熱, 蒸発潜熱等も考慮し, 以下のような定常二次 元熱収支式を考えた。

(流路)

$$
\begin{aligned}
& t_{\text {channel }} \cdot w_{\text {channel }} \frac{d}{d x}\left(k_{\text {gas }, k} \frac{d T}{d x}\right) \\
& =-\frac{d}{d x} \sum_{i} M_{i} \cdot H_{i-g a s, k}+w_{\text {channel }} \sum_{i} N_{i} \cdot H_{i-g a s, k}-w_{\text {channel }} \\
& \quad \times U_{\text {gas }, k-G D L, k}\left(T_{G D L, k}-T_{\text {gas }, k}\right) \\
& \quad-\left(w_{\text {channel }}+2 t_{\text {channel }}\right) \cdot U_{\text {gas }, k-\text { separator }}\left(T_{\text {channel }}-T_{\text {gas }, k}\right)
\end{aligned}
$$

(GDL)

$$
\begin{aligned}
& t_{G D L} \cdot w_{\text {separator }} \frac{d}{d x}\left(k_{G D L, k} \frac{d T}{d x}\right) \\
= & w_{\text {channel }} \sum_{i} N_{i}\left(H_{i-g a s, k}-H_{i-G D L, k}\right) \\
& -\sum_{i} w_{i} \cdot k_{G D L, k-i}\left(\frac{T_{G D L}-T_{i}}{d y}\right)-w_{\text {channel }} \cdot t_{G D L} \cdot \rho_{G D L} \cdot i(n)^{2} \\
& -w_{\text {channel }} \cdot U_{\text {gas }, k}\left(T_{\text {gas }, k}-T_{G D L, k}\right) \ldots \ldots \ldots \ldots .(12)
\end{aligned}
$$


(MEA)

$$
\begin{aligned}
t_{M E A} & \cdot w_{\text {separator }} \frac{d}{d x}\left(k_{M E A} \frac{d T}{d x}\right) \\
= & w_{\text {channel }} \sum_{i} N_{i} \cdot H_{i-G D L, k} \\
& -\sum_{k} w_{\text {channel }} \cdot k_{G D L, k-M E A}\left(\frac{T_{M E A}-T_{G D L, k}}{d y}\right) \\
& -w_{\text {channel }}\left[N_{i} \cdot H_{i}-i(n) \cdot\left(E-\eta_{\text {ohm }}-\eta_{\text {act }}\right)\right] \cdots
\end{aligned}
$$

$\langle\mathbf{2}$-5 濃度過電圧 GDL 中を通しての濃度過電圧を 直接測定することは難しいので，以下のように本研究にお ける濃度過電圧を推定した。GDL 中の濃度分布は膜厚方向 (y)に一次元流とし, 並列細孔モデル(4) を用いて, 濃度分布 を計算し, 濃度過電圧を推定してみた。酸素と水蒸気など がGDL 中を対抗して流れる場合も含めて，圧力や濃度の 分布は以下のように記述できる。

$$
\frac{d P}{d y}=\frac{-\left(N_{t}-\chi \cdot N_{1}\right) R T}{D_{22}}
$$

ここで,

$$
\begin{aligned}
& N_{t}=N_{1}+N_{2}, \quad \chi=1-D_{1} / D_{2}, \\
& D_{22}=D_{2}\left\{1+\left(X_{1} / D_{1}+X_{2} / D_{2}\right) B P / \mu\right\}, \\
& D_{i}=(d / 3) \cdot\left\{8 R T /\left(\pi m_{i}\right)\right\}^{0.5}, \\
& B=(\varepsilon / \tau) \cdot\left(d^{2} / 32\right), \quad X_{2}=1-X_{1}
\end{aligned}
$$

また, $y$ 方向のモル分率 $X_{1}$ の変化は次式で与えられる。

$$
\begin{aligned}
\frac{d X_{1}}{d y} \cdot \frac{\gamma P D}{R T}= & -N_{1}+X_{1} \gamma N_{t}+\left(N_{t}-\chi N_{1}\right) \\
& \times\left\{\gamma D X_{1}+\frac{X_{1}(1-\gamma) B P}{\mu}\right\} \frac{1}{D_{22}}
\end{aligned}
$$

ここで， $\gamma=D_{1} /\left(D_{1}+D\right), D$ は成分 $1 ， 2$ の文献(5)によ る二成分拡散係数である。濃度過電圧は細孔径分布に寄る が，適当な分布を仮定して濃度過電圧を推定してみた。

\section{3. 膜物性や過電圧の測定}

$\langle 3 \cdot 1\rangle$ GDL や MEA の水蒸気拡散係数や電気浸透の測 定 GDL を通しての水蒸気の拡散係数 $D_{G D L}$ や, MEA を通しての水蒸気の拡散係数 $D_{M E A}$ や電気浸透係数 $n_{d}$ は 前報 (1) と同じ方法で再測定し，測定結果は別に報告した ${ }^{(2)}$ 。 以下に測定結果の本解析への取り込み方を述べる。

空気需囲気中の水蒸気拡散係数 $D_{G D L}$ は $0.057 \sim 0.089$ $\left[\mathrm{cm}^{2} / \mathrm{s}\right]$ であった。60～ $80\left[{ }^{\circ} \mathrm{C}\right]$ における空気中の水蒸気の 二成分拡散係数 $D_{\mathrm{Air}-\mathrm{H}_{2} \mathrm{O}}$ は $0.311 \sim 0.344\left[\mathrm{~cm}^{2} / \mathrm{s}\right]$ である ${ }^{(5)}$ 。 $D_{G D L}$ が $D_{A i r-\mathrm{H}_{2} \mathrm{O}}$ を使って以下の式で近似できるとすれば, 本研究で用いた GDLの $\varepsilon / \tau$ (空隙率/屈曲率) は 0.21 と推 定できる。

$$
D_{G D L}=\frac{\varepsilon}{\tau} \cdot D_{A i r-\mathrm{H}_{2} \mathrm{O}}
$$

一方，水素䨌囲気中の $D_{G D L}$ は $0.04 \sim 0.11$ であり， $\varepsilon / \tau$ は
0.09 と推定できた。また, $D_{M E A}$ は $0.92 \sim 14 \times 10^{-3}\left[\mathrm{~cm}^{2} / \mathrm{s}\right]$ となった。 $n_{d}$ は 1.0〜 1.5 となり, 相対湿度 $a$ に対しほぼ 一定であった。Nguyen ら (2) の整理式を参考に以下のよう に近似し, $D_{M E A}$ は $n_{d}$ と $a$ の関数とし, $n_{d}$ は $a$ の変化に 対し一定で, 膜温度 $T_{M E A}[\mathrm{~K}]$ の関数として, 解析に取り込 んだ。

$$
\begin{array}{r}
D_{M E A}=n_{d} \cdot\left(6.10 \times 10^{-4}+4.50 \times 10^{-3} a\right. \\
\left.+5.33 \times 10^{-4} a^{2}+5.47 \times 10^{-3} a^{3}\right) \\
\ldots \ldots \ldots \cdots
\end{array}
$$

〈3・2〉 MEA の膜抵抗の測定 MEA の膜抵抗につい ても前報 ${ }^{(1)}$ と同じ方法で再測定し再整理した。抵抗過電圧 $\eta_{\text {ohm }}$ は, 次式で求めた。

$$
\eta_{o h m}=\left(\frac{1}{a_{a}-a_{c}} \int_{a_{c}}^{a_{a}} \rho d a\right) t_{M E A} \cdot i(x) .
$$

ここで測定した膜抵抗率 $\rho$ の流体の相対湿度 $a$ と膜温度 $T_{M E A}$ に対する変化を図 2 に示す。 $T_{M E A}$ または $a$ を上げる と, Nguyen ら ${ }^{(3)}$ と同様に $\rho$ は小さくなった。我々が測定 した膜はNguyen らの Nafion117 と異なり，また，我々の 測定には接触抵抗が含まれるので, 我々の $\rho$ はNguyen ら より大きかった。測定した $\rho$ は $T_{M E A}$ と $a$ の関数として次 式で整理し解析に用いた。

$$
\begin{aligned}
\rho= & {\left[0.310 T_{M E A}^{2}-2.22 \times 10^{2} T_{M E A}+4.04 \times 10^{4}\right] } \\
& \times \exp \left(\frac{-a}{0.284}\right) \\
& +\left[5.51 T_{M E A}^{2}-3.91 \times 10^{3} T_{M E A}+6.99 \times 10^{5}\right] \\
& \times \exp \left(\frac{-a}{0.0483}\right) \quad[\Omega \mathrm{cm}] \cdots \cdots \cdots \cdots \cdots
\end{aligned}
$$

〈3·3〉 PEFC の活性化過電圧の測定 活性化過電圧 $\eta_{a c t}$ についても前報 ${ }^{(1)}$ と同じように再測定し, 再整理した。 (10) 式を次式のように変形し，アノードとカソードを含め て $\eta_{\text {act }}$ として整理した。

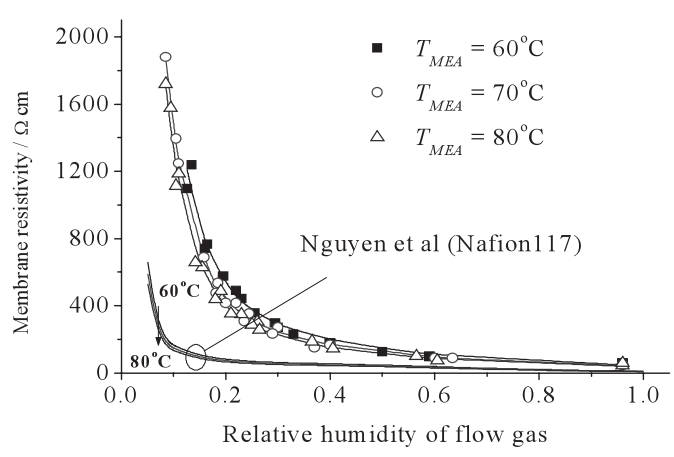

図 2 膜抵抗率の温度相対湿度に対する変化

Fig. 2. Change of membrane resistance by temperature and relative humidity. 


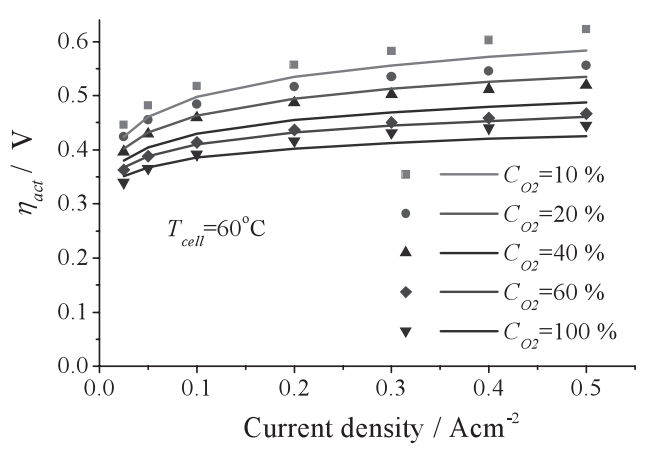

図 3 活性化過電圧の電流密度と酸素濃度に対する変化

Fig. 3. Change of activation overpotential by current density and $\mathrm{O}_{2}$ concentration.

$$
\eta_{\text {act }}=E-V_{\text {cell }}-\eta_{\text {ohm }}
$$

$\eta_{\text {act }}$ は酸素分圧 $P_{\mathrm{O}_{2}}$ と平均電流密度 $i$, 七儿温度 $T_{\text {cell }}$ を変 化させて測定した。 $T_{\text {cell }}$ は $50,60,70,80^{\circ} \mathrm{C}$ とし, 露点 温度は $T_{\text {cell }}$ と同じとし，アノードには水素，カソードには 次式に示す酸素割合で，10，20，40，60，100\%と変えた 酸化剂を流した。

$$
C_{\mathrm{O}_{2}}=\frac{M_{\mathrm{O}_{2}}}{M_{\mathrm{O}_{2}}+M_{\mathrm{N}_{2}}} \times 100 \quad[\%]
$$

図 3 に $60^{\circ} \mathrm{C}$ で測定した $\eta_{a c t}$ を代表としてを示す。記号は 実験点を，実線は (23) 式に示す近似式で求めた結果を示す。 $\eta_{a c t}$ は以下のターフェル式で近似し，係数 A, B は $P_{\mathrm{O}_{2}}[\mathrm{~atm}]$ と $T_{\text {cell }}$ の関数とした。整理式 (23) は実測を $\eta_{\text {act }}$ 誤差 $5 \%$ 以 内で近似している。

$$
\left.\begin{array}{rl}
\eta_{\text {act }}= & A+B \ln i \\
A= & {\left[-5.15 \times 10^{-4}\left(T_{\text {cell }}+273.15\right)+9.53 \times 10^{-2}\right]} \\
& \times \ln P_{\mathrm{O}_{2}}+0.433 \\
B= & {\left[-1.44 \times 10^{-4}\left(T_{\text {cell }}+273.15\right)+3.58 \times 10^{-2}\right]} \\
& \times \ln P_{\mathrm{O}_{2}}+0.0234
\end{array}\right\}
$$

$T_{\text {cell }}=60^{\circ} \mathrm{C}$ の時, カソードに $\mathrm{O}_{2}$ あるいは空気を流し, 露 点温度を $60,50,40,30^{\circ} \mathrm{C}$ と下げて $\eta_{a c t}$ を測定したが, $\eta_{\text {act }}$ は (23) 式に一致した。なお，この $\eta_{\text {act }}$ には GDLを通 しての濃度過電圧も含まれてしまうが, この誤差について は〈4・7〉節で考察する。

\section{4. 電流分布の測定と解析結果との比較}

$\langle\mathbf{4} \cdot \mathbf{1}\rangle$ 電流分布の測定方法 測定した膜物性などを 用いた解析結果の信頼性を確認するため, 前報と同じよう に電流分布を測定し(1)，解析結果と比較・検討した。電流 分布は図 4 に示す分割電極セルを用い, co-flow（並行流） と counter-flow（対向流）のセル流れに対し，酸素利用率 や加湿温度を变えて測定し比較した。分割電極セルは, 一 方の電極は分割されてアクリルフレーム中に固定され，各 分割電極はシャント抵抗 $(12 \mathrm{~m} \Omega)$ に接続され，その電圧 降下から流れに沿う電流分布を測定した。また, 分割電極

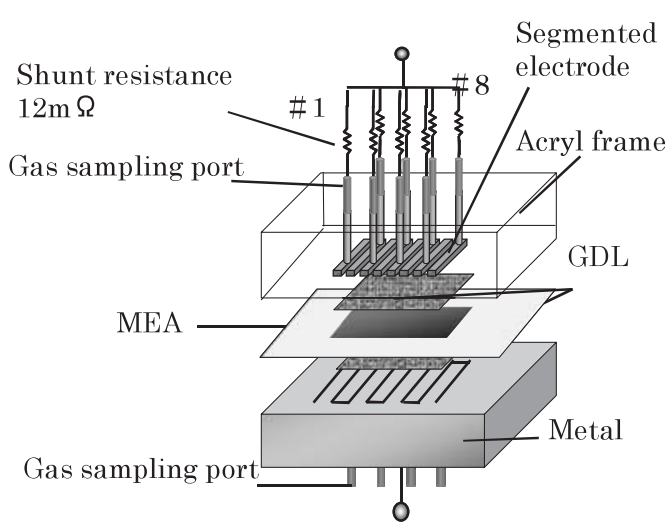

\begin{tabular}{|c|c|c|c|c|c|c|}
\hline \multirow[b]{2}{*}{$\begin{array}{c}\text { Experimental } \\
\text { number }\end{array}$} & 1 & 2 & 3 & 4 & 5 & 6 \\
\hline & $\begin{array}{c}\text { co } \\
\text {-flow }\end{array}$ & $\begin{array}{l}\text { counter } \\
\text {-flow }\end{array}$ & $\begin{array}{c}\text { co } \\
\text {-flow }\end{array}$ & $\begin{array}{c}\text { counter } \\
\text {-flow }\end{array}$ & $\begin{array}{c}\text { co } \\
\text {-flow }\end{array}$ & $\begin{array}{c}\text { counter } \\
\text {-flow }\end{array}$ \\
\hline $\begin{array}{c}Q \\
{[\mathrm{cc} / \mathrm{min}]}\end{array}$ & \multicolumn{2}{|c|}{$\begin{array}{l}\mathrm{H}_{2}: 300 \\
\mathrm{O}_{2}: 300\end{array}$} & \multicolumn{2}{|c|}{$\begin{array}{c}\mathrm{H}_{2}: 40 \\
\text { Air }: 100\end{array}$} & \multicolumn{2}{|c|}{$\begin{array}{l}\mathrm{H}_{2}: 40 \\
\mathrm{O}_{2}: 40\end{array}$} \\
\hline $\begin{array}{l}T_{\text {cell }} \\
{\left[{ }^{\circ} \mathrm{C}\right]}\end{array}$ & \multicolumn{4}{|c|}{60} & \multicolumn{2}{|c|}{60} \\
\hline $\begin{array}{c}\text { anode } \\
T_{D P}\left[{ }^{\circ} \mathrm{C}\right]\end{array}$ & \multicolumn{4}{|c|}{59} & \multicolumn{2}{|c|}{30} \\
\hline $\begin{array}{l}\text { cathode } \\
T_{D P}\left[{ }^{\circ} \mathrm{C}\right]\end{array}$ & \multicolumn{4}{|c|}{59} & \multicolumn{2}{|c|}{30} \\
\hline $\begin{array}{c}\xi \\
{[\%]}\end{array}$ & \multicolumn{2}{|c|}{$\begin{array}{c}\mathrm{H}_{2}: 2.5 \sim 17.7 \\
\mathrm{O}_{2}: 1.3 \sim 8.9\end{array}$} & \multicolumn{2}{|c|}{$\begin{array}{l}\mathrm{H}_{2}: 19 \sim 95 \\
\mathrm{O}_{2}: 19 \sim 95\end{array}$} & \multicolumn{2}{|c|}{$\begin{array}{c}\mathrm{H}_{2}: 19 \sim 95 \\
\mathrm{O}_{2}: 9.5 \sim 47.5\end{array}$} \\
\hline $\begin{array}{c}i_{\text {ave }} \\
{\left[\mathrm{A} / \mathrm{cm}^{2}\right]}\end{array}$ & \multicolumn{2}{|c|}{$0.1 \sim 0.7$} & \multicolumn{2}{|c|}{$0.1 \sim 0.5$} & \multicolumn{2}{|c|}{$0.1 \sim 0.5$} \\
\hline
\end{tabular}

図 4 電流分布測定用分割電極セル

Fig. 4. Segmented electrodes cell.

表 1 電流分布測定の実験条件

Table 1. Experimental condition of for current distribution measurement.

に接続したガス採取管から流路に沿ってガスを少量採取し， ガスクロでガス組成を分析し，電流分布に換算した。

$\langle\mathbf{4} \cdot \mathbf{2}\rangle$ 実験条件 今回測定した実験条件を表 1 に示 す。同表で $Q$ は流量, $T_{D P}$ は加湿温度, $\xi_{\mathrm{H}_{2}}, \xi_{\mathrm{O}_{2}}$ はそれぞ れ水素利用率, 酸素利用率, $i_{\text {ave }}$ は平均電流密度で, 以下 では加湿や酸素利用率，七ル流れが電流分布に与える影響 を述べる。また, ガスクロによる電流分布の測定は, 本報 告では表 1 の低加湿, 中酸素利用率の並行流の実験 5 につ いて報告する。なお，本報告では $0.5 \mathrm{~A} / \mathrm{cm}^{2}$ のときの利用 率が 20\%以下の時を低利用率，80\%以上の時を高利用率と し，その間を中利用率と表現した。

$\langle\mathbf{4} \cdot \mathbf{3}\rangle$ 高加湿, 低酸素利用率の時の電流分布の測定と 解析との比較 高加湿で低酸素利用率の並行流の実験 1 に扔ける電流分布を図 5(a) に測定と解析を比較して示す。 図 5(b) には $i_{\text {ave }}=0.7 \mathrm{~A} / \mathrm{cm}^{2}$ の時のセル内電圧分布の解析 結果を示す。図 5(b) に示すように, 高加湿, 低酸素利用率 の条件では膜抵抗と活性化過電圧はほぼ一定となるため, 電流分布も一定となることが解析より分かる。実験 2 の対 向流についても, 紙面の都合上ここには示さないが, 同じ ように電流分布は一定となった。 


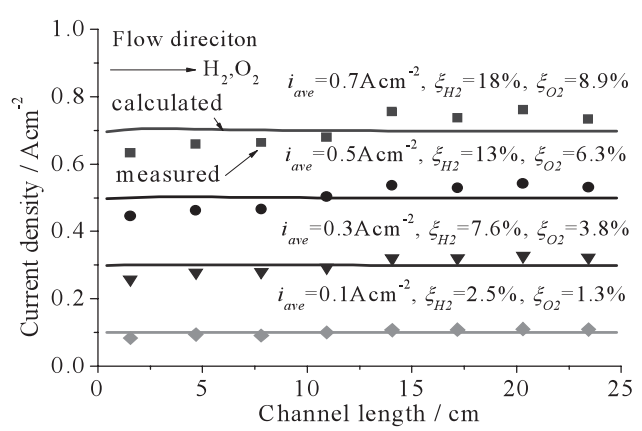

(a)

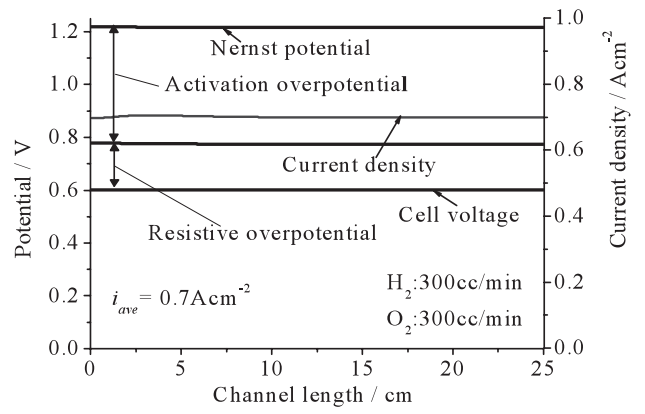

(b)

図 5 高加湿，低酸素利用率における測定と解析電流分布との比較（並行流）

Fig. 5. Comparison between measured and calculated current distributions at high dew point temperature and low $\mathrm{O}_{2}$ utilization ratio (co-flow).

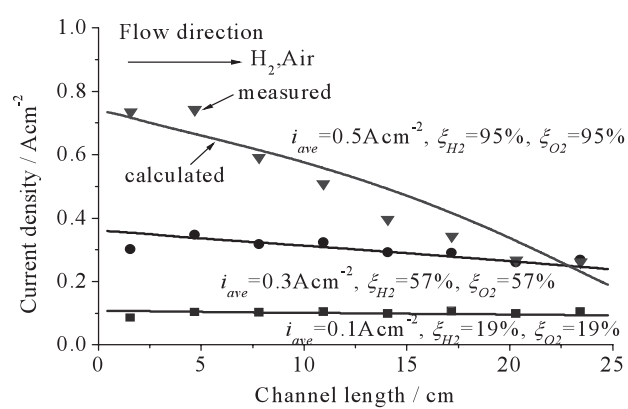

(a)

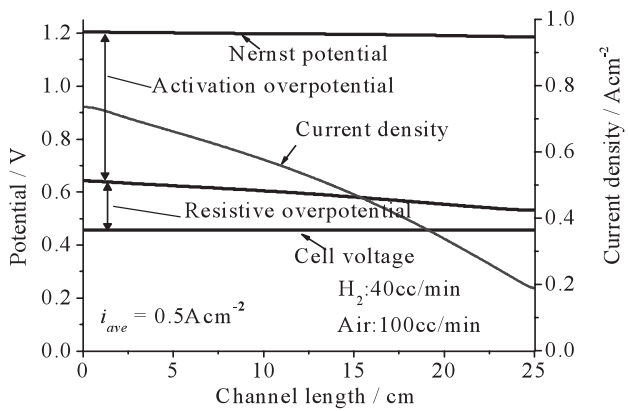

(b)

図 6 高加湿，高酸素利用率における測定と解析電流分布との比較（並行流）

Fig. 6. Comparison between measured and calculated current distributions at high dew point temperature and high $\mathrm{O}_{2}$ utilization ratio (co-flow).

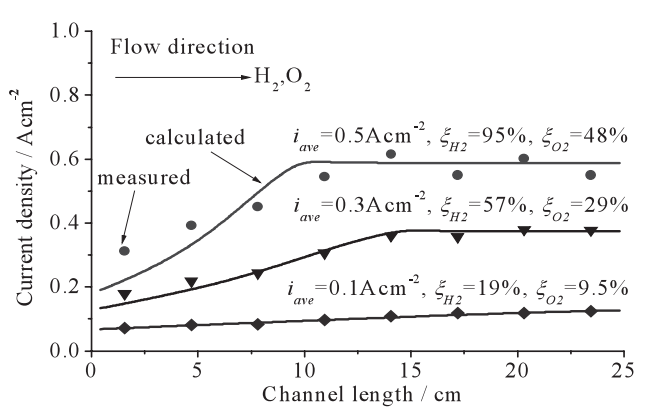

(a)

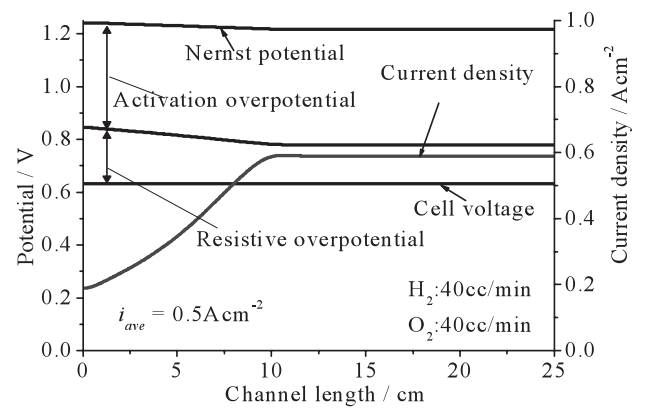

(b)

図 7 低加湿, 中酸素利用率における測定と解析電流分布との比較（並行流）

Fig. 7. Comparison between measured and calculated current distributions at low dew point temperature and medium $\mathrm{O}_{2}$ utilization ratio (co-flow).

$\langle\mathbf{4} \cdot \mathbf{4}\rangle$ 高加湿, 高酸素利用率の時の電流分布の測定と 解析との比較 高加湿, 高酸素利用率の並行流の実験 3 について図 6(a) に測定と解析を比較して示す。図 6(b) に $i_{\text {ave }}=0.5 \mathrm{~A} / \mathrm{cm}^{2}$ の時のセル内電圧分布の解析結果を示す。 図 6(b) に示すように，高酸素利用率の条件では，流れに 沿って反応が進み酸素分圧が減るため，ネルンスト起電力 が下がり, 活性化過電圧が大きくなり, 電流分布は出口に 向かって下がることが解析から分かる。実験 4 の対向流に ついては，紙面の都合上ここには示さないが，同じょうに 酸素の流れ方向に電流が下がる分布となった。 $\langle\mathbf{4} \cdot \mathbf{5}\rangle$ 低加湿, 中酸素利用率の時の電流分布の測定と 解析との比較 低加湿, 中酸素利用率の並行流の実験 5 の分割電極セルに抒ける電流分布を図 7(a) に測定と解析を 比較して示す。図 7(b) には $i_{\text {ave }}=0.5 \mathrm{~A} / \mathrm{cm}^{2}$ の時のセル内 電圧分布の解析結果を示す。図 (b) に示すように, 低加湿, 中酸素利用率の条件では, 入口で膜抵抗が大きく, やがて 生成水により膜が湿潤し膜抵抗が下がる。一方, 下流で活 性化過電圧は酸素分圧の低下と共に大きくなるため, 電流 分布は入口から出口に向けて増え, やがて一定になること が解析から分かる。 


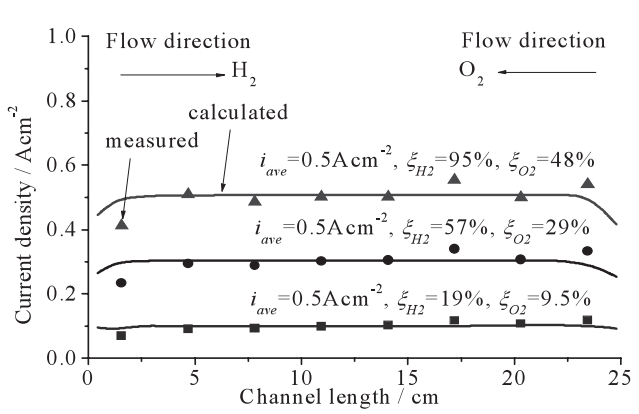

(a)

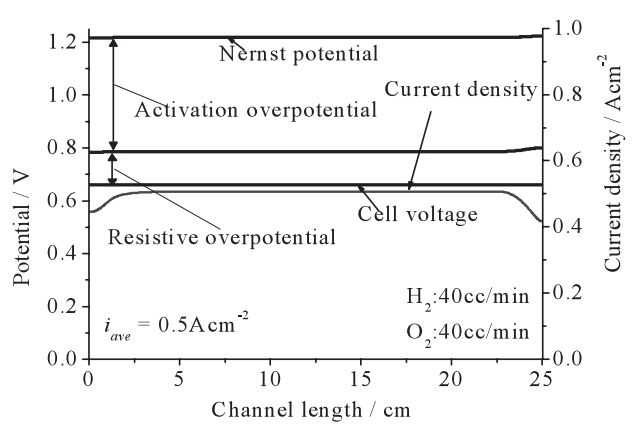

(b)

図 8 低加湿，中酸素利用率における測定と解析電流分布との比較（対向流）

Fig. 8. Comparison between measured and calculated current distributions at low dew point temperature and medium $\mathrm{O}_{2}$ utilization ratio (counter-flow).

低加湿, 中酸素利用率の対向流の実験 6 における電流 分布を図 8(a) に測定と解析を比較して示す。図 8(b) には $i_{\text {ave }}=0.5 \mathrm{~A} / \mathrm{cm}^{2}$ の時のセル内電圧分布の解析結果を示す。 図 7(b) に示すように, 低加湿, 中酸素利用率の条件では $\mathrm{O}_{2}$ と $\mathrm{H}_{2}$ が対向して流れるため, 両端では膜抵抗が幾分大き いが，生成水により中央で抵抗は下がり一定となる。一方， 活性化過電圧変化は大きく変化しないため, 電流分布は両 端で小さく, 中程で一定となることが解析から分かる。こ のように，低加湿，中酸素利用率ではセル両端で電流は下 がるものの，並行流を対向流にすることで電流は均一に分 布し, 更に, セル電圧が $0.62 \mathrm{~V}$ から $0.65 \mathrm{~V}$ に回復し, 発 電特性も改善することが分かる。

表 1 に示した実験条件では図 5～図 8 に示したように, 電流分布の解析值は測定值と $10 \%$ 以内で一致することが分 かった。我々が開発した解析プログラムはこのように広い 運転範囲で実験的に確認することができた。

〈4·6〉 ガスクロによる電流分布測定 低加湿, 中酸素 利用率の並行流の実験 5 のガスクロによる電流分布の測定 結果を図 9 に示す。図 9 は平均電流密度 $i_{a v e}=0.5 \mathrm{Acm}^{-2}$ の場合であり， $\mathrm{N}_{2}$ を基準とした $\mathrm{H}_{2}, \mathrm{O}_{2}$ の濃度变化より電 流換算した值である。図 9 のようにガスクロによる電流分 布は分割電極セルで測定した電流分布とほぼ一致した。こ のため，本報告では測定が容易な分割電極セルで測定した 電流分布と解析結果を比較した。

$\langle\mathbf{4} \cdot \mathbf{7}\rangle$ 濃度過電压の試算 GDL 中の濃度分布 を〈2.5〉節で述べた並列細孔モデル ${ }^{(4)}$ で計算し, 濃度過 電圧を推定した。(14) 式の $\varepsilon / \tau$ はく $3 \cdot 1\rangle$ 節で測定した 0.21 とした。ただし，本研究で用いた GDLの空孔径分布を測 定していないため, 平均細孔径 $d$ としては固体酸化物燃料 電池での測定例 $3 \mu \mathrm{m}^{(4)}$ とその 10 倍の $30 \mu \mathrm{m}$ の 2 つを試算 してみた。両者とも同程度の過電圧であり，実験 1 の条件 ではカソード濃度過電圧は $100 \mu \mathrm{V}$ 程度, アノードで $10 \mu \mathrm{V}$ 程度であった。また，他の条件でも濃度過電圧全体で $1 \mathrm{mV}$ 以下と試算され，PEFCの発電特性に影響するまでには到 らなかった。

〈4·8〉 カソードのフラッディングの影響＼cjkstart本研究で

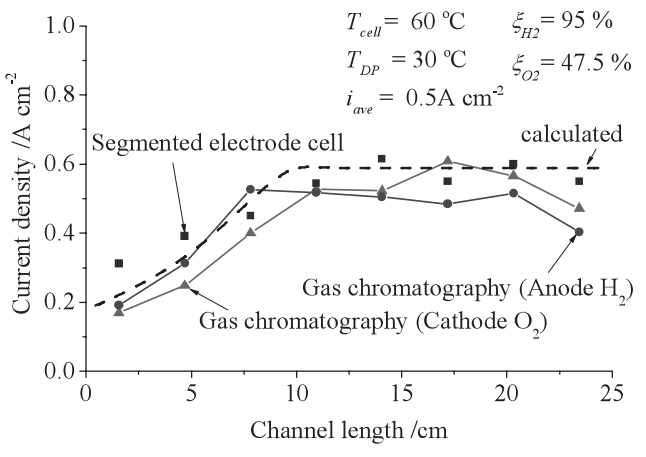

図 9 ガスクロによる電流分布

Fig. 9. Current density of gas chromatography.

はカソードでのフラッディングを定量化する測定は行って いないが，七ル内での水の挙動を推定するため，高加湿運 転で $\mathrm{H}_{2}, \mathrm{O}_{2}$ の利用率を $95 \%$ とした時，(24) 式で定義する 湿り度 $\beta$ を, 実験 3,4 に対する場合と, 実験 3 の空気を 酸素に変えた場合に対して, その解析值を図 10 に示す。

$$
\beta=\frac{M_{\mathrm{H}_{2} \mathrm{O}}^{l}+M_{\mathrm{H}_{2} \mathrm{O}}^{v}}{M_{\mathrm{H}_{2} \mathrm{O}}^{v}} .
$$

空気の並行流ではカソードの湿り度は下流に向かって増え, 出口付近で約 3 となった。それに対して酸素の場合は出口 で 100 以上にもなった。どちらも $i_{a v e}$ が同じであるので生 成水量も同じであるが, 酸素の場合は空気に比べ窒素が無 い分出口に向けて水蒸気分圧が増加するため, 大部分の水 蒸気が飽和蒸気圧を超え凝縮し, 湿り度が上昇した。 $n_{d}$ が 1 弱であるので，アノードでは消費される水素の 2 倍弱の 水蒸気がカソードへ電気浸透し乾き状態になるが, 逆拡散 でほぼ等量の水蒸気がカソードから帰ってくるため, 湿り 度はほぼ 1 であった。対向流の場合はカソードの流れが逆 方向になるため, 分布形は逆になり，水蒸気が再循環する ので，カソードの湿り度は出口で僅かに高くなった。

図 10 と同じ酸素カソードで発電実験を行うと, PEFCの 出力電圧は不安定となり, 安定した運転はできなかった。 一方，空気の場合は並行流でも対向流でも安定した実験が できたので, 本研究のセル構成では湿り度は 3 程度までフ 


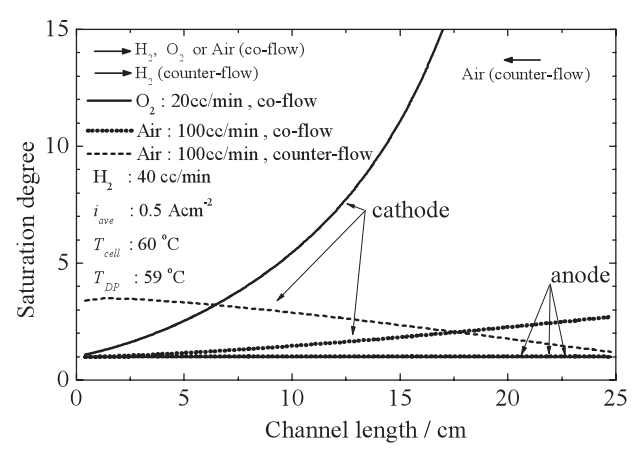

図 10 湿り度の流れ方向分布

Fig. 10. Distribution of wetness along flow direction.

ラッディングによる動作不良はないようである。

なお，本研究ではセパレータに恒温水を流したため, $\langle 2 \cdot 4\rangle$ 節のエネルギー収支式で温度分布も計算したが，多 くの場合 MEA \& GDL も $2^{\circ} \mathrm{C}$ 以内でセパレータ温度に一 致した。カソード流路で水蒸気が凝縮する時, カソードガ スが $6^{\circ} \mathrm{C}$ 程度温度上昇する場合もあったが，発電特性に影 響する程ではなかった。

\section{5. まとめ}

発電実験に用いた膜電極接合体（MEA）の水蒸気に対す る拡散係数や電気浸透係数を，また，ガス拡散層 (GDL) の 水蒸気拡散係数を測定し, 更に MEA の膜抵抗や活性化過 電圧を測定し，解析コードに取り込めるよう整理した。こ れらの膜物性などを用い，質量・電荷やエネルギー収支式 を等価回路と連立させ，我々が開発した固体高分子燃料電 池 (PEFC) の解析コードで電流密度分布を計算した。解析 結果の信頼性を確認するため分割電極セルで電流分布を測 定したところ，本研究の実験範囲では，測定值と解析值は， $10 \%$ 以内で一致した。このことより，膜物性や過電圧など を実測し解析に用いれば，我々の開発したPEFC 発電特性 解析プログラムで，広い運転範囲で電流分布を予測できる ことが分かった。

\section{謝 辞}

本研究の一部は NEDO, PEFC 要素技術開発等事業／先 導的基礎技術研究開発として行われたこと, 中部ガス（株） の支援を受けたことを付記し，ここに感謝の意を表する。

(平成 18 年 2 月 14 日受付, 平成 18 年 5 月 25 日再受付)

\section{文献}

(1) H. Koori, T. Taniuchi, T. Araki, and K. Onda: "Measurement of Physical Properties of Membrane and Analysis of Current Density Distribution at a Polymer Electrolyte Fuel Cell”, IEEJ Trans. PE, Vol.125, No.5, pp.530-536 (2005-5) (in Japanese)

郡 央任 ·谷内拓哉·荒木拓人 · 恩田和夫 : 「固体高分子燃料電池の 膜物性測定と電流分布解析」, 電学論 B, 125, 5, pp.530-536 (2005-5)

(2) D. Sunakawa, S. Oyama, T. Araki, and K. Onda: "Measurement of PEFC membrane properties", Electrochem (to be submitted)

(3) T.V. Nguyen and R.E. White: "A Water and Heat Management Model for Proton-Exchange-Membrane Fuel Cells", J. Electrochem. Soc., Vol.140, No.8, p.2178 (1993)
（4） 丸本健二・綾 淳・松井安治：「ガス透過率測定による固体電解質 燃料電池の構成要素の評価」, 機械学論 B, Vol.56, No.532, pp.268-273 (1990)

(5) B.E. Poling, J.M. Prausnitz, and J.P. O'connell: The properties of gases and liquids, fifth edition, pp.11.10-11.14, M'cGraw Hill, New York, NY (2000)

\section{付 録}

記 号

$a$ : ガス流路における相対湿度 [-]

$d:$ 細孔径 $[\mathrm{m}]$

$i(n)$ : 電流密度 $\left[\mathrm{A} / \mathrm{cm}^{2}\right]$

$k_{c}$ : 凝縮係数 $\left[\mathrm{s}^{-1}\right]$

$m_{i}$ : 分子種 $i$ の分子量 $[\mathrm{kg} / \mathrm{mol}]$

$n_{d}:$ 電気浸透係数 [-]

$t_{M E A}:$ MEA の膜厚 $[\mathrm{cm}]$

$t_{j}: j$ の厚さ $[\mathrm{cm}]$

$w_{j}: j$ の幅 $[\mathrm{cm}]$

$x$ : ガス流れ方向 $[\mathrm{cm}]$

$y:$ 膜厚方向 $[\mathrm{cm}]$

$C_{i}$ : ガス種 $i$ のガス濃度 $\left[\mathrm{mol} / \mathrm{cm}^{3}\right]$

$D_{i}$ : ガス種 $i$ の拡散係数 $\left[\mathrm{cm}^{2} / \mathrm{s}\right]$

$D_{M E A}$ ：MEA における拡散係数 $\left[\mathrm{cm}^{2} / \mathrm{s}\right]$

$D_{G D L}$ : GDL における拡散係数 $\left[\mathrm{cm}^{2} / \mathrm{s}\right]$

$D_{\text {Air }-\mathrm{H}_{2} \mathrm{O}}$ : 空気中の水蒸気の拡散係数 $\left[\mathrm{cm}^{2} / \mathrm{s}\right]$

$D_{\mathrm{H}_{2} \mathrm{O}}$ : 水の拡散係数 $\left[\mathrm{cm}^{2} / \mathrm{s}\right]$

$E^{o}$ : 標準起電力 [V]

$E:$ Nerunst 起電力 $[\mathrm{V}]$

$F$ : ファラデー定数 $[\mathrm{C} / \mathrm{mol}] H_{i}$ : ガス種 $i$ のエンタ

ルピ $[\mathrm{J} / \mathrm{mol}]$

$M_{i}$ : ガス種 $i$ のル流量 $[\mathrm{mol} / \mathrm{s}]$

$N_{i}$ : ガス種 $i$ のモル流速 $\left[\mathrm{mol} / \mathrm{cm}^{2} / \mathrm{s}\right]$

$P$ : 圧力 $[\mathrm{atm}]$ あるいは $[\mathrm{Pa}]$

$P_{\mathrm{H}_{2} \mathrm{O}, k}:$ 水蒸気圧 $[\mathrm{atm}]$

$Q:$ ガス流量 $[\mathrm{cc} / \mathrm{min}]$

$R:$ 気体乗数 $[\mathrm{J} / \mathrm{mol} / \mathrm{K}]$

$T:$ 流路内温度 $[\mathrm{K}]$

$T_{M E A}$ : 膜温度 [K]

$T_{\text {cell }}$ : セル温度 $\left[{ }^{\circ} \mathrm{C}\right]$

$U$ : 熱伝達係数 $\left[\mathrm{W} / \mathrm{cm}^{2} / \mathrm{K}\right]$

$V_{\text {cell }}:$ セル電圧 $[\mathrm{V}]$

$X_{i}$ : ガス種 $i$ のモル分率 [-]

$\alpha$ : プロトン流束に対する正味の水移動流束 [-]

$\beta$ : 湿り度 [-]

$\varepsilon$ : ガス拡散電極の有効空隙率 [-]

$\eta_{\text {act }}$ : 活性化過電圧 [V]

$\eta_{o h m}$ : 抵抗過電圧 [V]

$\mu$ : 粘性係数 $\left[\mathrm{N} \cdot \mathrm{s} / \mathrm{cm}^{2}\right]$

$k$ : 熱伝導率 $[\mathrm{W} / \mathrm{cm} / \mathrm{K}]$

$\xi_{\mathrm{H}_{2}}$ : 水素利用率 [-]

$\xi_{\mathrm{O}_{2}}$ : 酸素利用率 [-]

$\rho$ : 膜抵抗率 $[\Omega \mathrm{cm}]$ 
$\tau:$ ガス拡散電極の屈曲率 [-]

$$
\begin{aligned}
& \text { 添 } \quad \text { 字 } \\
& k: a(\text { アノード }), c \text { (カソード }) \\
& l: \text { 液体 } \\
& v: \text { 蒸気 } \\
& \text { sat }: \text { 飽和状態 } \\
& \text { ave }: \text { 平均 } \\
& D P: \text { 露点温度 }
\end{aligned}
$$

谷内拓 哉 (学生員) 1982 年 2 月 22 日生。 2004 年 3 月豊

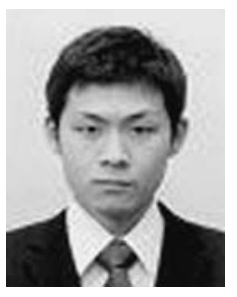
橋技術科学大学電気電子工学課程卒業。同年 4 月 豊橋術科学大学大学院工学研究科電気電子工学専 攻入学, 現在に至る。主に燃料電池の研究に従事。

若 原 健 二 (学生員) 1982 年 10 月 16 日生。 2005 年 3 月豊

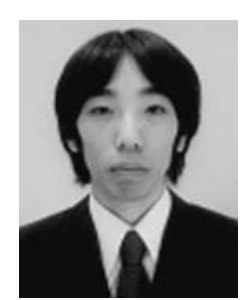
橋技術科学大学電気電子工学課程卒業。同年 4 月 豊橋術科学大学大学院工学研究科電気電子工学専 攻入学, 現在に至る。主に燃料電池, 二次電池の 研究に従事。
長 濱 光 幸 (学生員) 1983 年 10 月 23 日生。 2006 年 3 月豊

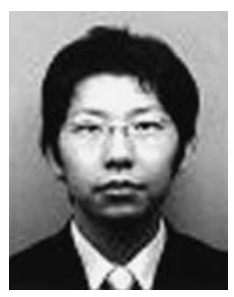
橋技術科学大学電気電子工学課程卒業。同年 4 月 豊橋術科学大学大学院工学研究科電気電子工学専 攻入学, 現在に至る。主に燃料電池の研究に従事。

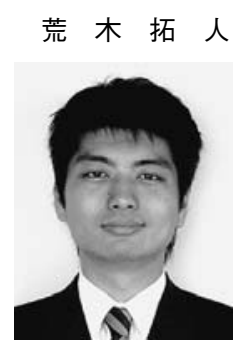

(正員) 1975 年 5 月 2 日生。 2003 年 3 月京都大 学大学院工学研究科博士課程修了。2004 年 1 月 豊橋技術科学大学助手 (電気電子工学系)。主と して, 燃料電池, 水電解, 二次電池, 放電脱硝の 研究に従事。電気化学会, 機械学会, 伝熱学会会 員。工学博士。
恩 田 和 夫（正員） 1941 年 6 月 20 日生。1966 年 3 月東京

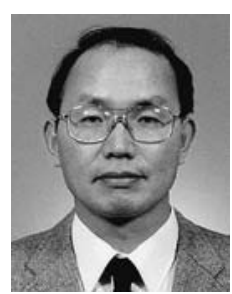

工業大学大学院理工学研究科修士課程修了。同年 10 月電子技術総合研究所入所。1 995 年 9 月豊橋 技術科学大学教授 (電気電子工学系)。主として, 燃料電池, 水電解, 二次電池, 放電脱硝の研究に 従事。電気化学会, 応用物理学会, 日本機械学会, エネルギー・資源学会会員。工学博士。 